\title{
Genetic and Environmental Interaction in Type 1 Diabetes: a Relationship Between Genetic Risk Alleles and Molecular Traits of Enterovirus Infection?
}

\author{
Marfa Blanter $^{1,2} \cdot$ Helena Sork $^{1} \cdot$ Soile Tuomela ${ }^{1} \cdot$ Malin Flodström-Tullberg $^{1}$ \\ Published online: 10 August 2019 \\ (C) The Author(s) 2019
}

\begin{abstract}
Purpose of Review We provide an overview of the current knowledge regarding the natural history of human type 1 diabetes (T1D) and the documented associations between virus infections (in particular the enteroviruses) and disease development. We review studies that examine whether T1D-specific risk alleles in genes involved in the function of the immune system can alter susceptibility to virus infections or affect the magnitude of the host antiviral response. We also highlight where the major gaps in our knowledge exist and consider possible implications that new insights gained from the discussed gene-environment interaction studies may bring.

Recent Findings A commonality between several of the studied T1D risk variants studied is their role in modulating the host immune response to viral infection. Generally, little support exists indicating that the risk variants increase susceptibility to infection and moreover, they usually appear to predispose the immune system towards a hyper-reactive state, decrease the risk of infection, and/or favor the establishment of viral persistence.

Summary In conclusion, although the current number of studies is limited, this type of research can provide important insights into the mechanisms that are central to disease pathogenesis and further describe how genetic and environmental factors jointly influence the risk of T1D development. The latter may provide genetic markers that could be used for patient stratification and for the selection of method(s) for disease prevention.
\end{abstract}

Keywords Autoimmune $\cdot$ Enterovirus $\cdot$ Environment $\cdot$ Genome-wide association studies $\cdot$ Immune system $\cdot$ Type 1 diabetes

This article is part of the Topical Collection on Pathogenesis of Type 1 Diabetes

Malin Flodström-Tullberg

malin.flodstrom-tullberg@ki.se

Marfa Blanter

marfablanter@hotmail.com

Helena Sork

helena.sork@ki.se

Soile Tuomela

soile.tuomela@ki.se

1 Center for Infectious Medicine, Department of Medicine Huddinge, Karolinska Institutet, Karolinska University Hospital,

Stockholm, Sweden

2 Laboratory of Molecular Immunology, Department of Microbiology and Immunology, Rega Institute for Medical Research, University of Leuven, Leuven, EU, Belgium

\section{Introduction}

Type 1 diabetes (T1D) is characterized by reduced insulin production due to a loss of the insulin-producing pancreatic $\beta$ cells [1]. Disease onset typically takes place in childhood or young adulthood and in some countries the incidence is as high as 40-60 new cases per 100,000 children per year [2]. T1D is one of the most common chronic diseases in children and will, if left untreated, eventually lead to deadly coma [3]. Treatment consists of daily insulin administration and glucose monitoring. Most individuals with T1D have to cope with frequent hypo- and hyperglycemic episodes and have a high risk of developing various micro- and macrovascular complications associated with serious morbidity and a shortened life expectancy $[4,5]$. While the etiology and pathogenesis of human T1D are not fully understood, both genetic and environmental factors seem to play an important role in regulating risk for disease development. 


\section{The Natural History of Human T1D}

Many observations point to the hypothesis that T1D is an immune-mediated disease involving the actions or regulatory failure of multiple compartments of the immune system. Prior to clinical disease manifestation, autoantibodies directed against $\beta$ cell antigens are detectable in the blood of most individuals for a period of months to several years [1]. At disease onset, the pancreatic islets of most patients show hyperexpression of MHC class I [6•,7] and many islets are infiltrated by immune cells $[8,9]$. The immune infiltrate is mainly composed of $\mathrm{CD} 8^{+} \mathrm{T}$ cells, although $\mathrm{CD} 4^{+} \mathrm{T}$ cells, $\mathrm{B}$ cells, and cells of the innate immune system are also present [10-12]. Based on these observations, the most frequently presented hypothesis regarding how T1D arises states that $\beta$ cells are destroyed by autoreactive $\mathrm{CD} 8^{+} \mathrm{T}$ cells and that the appearance of autoantibodies in the prediabetic period marks the initiation of the autoimmune disease process. However, data from a large body of recent work assessing the human pancreas near to or at disease onset have demonstrated that the $\beta$ cells are still present in many patients (recently reviewed in [13•]), including those individuals who have lived with the disease for more than 50 years [14]. Moreover, the degree of insulitis seems to differ between patients and variation even exists in different lobes of a single patient's pancreas [10, 15 , 16]. Age-related differences in the immune cell composition of the islet infiltrates have also been identified [11, 12], and, intriguingly, the relative pancreas size is reportedly smaller both at disease onset and in autoantibody-positive subjects as well as first-degree relatives $[17,18]$. These findings underscore the fact that there is still much to be learned about the natural history of human T1D.

\section{The Genetic Background of T1D}

While it is as of yet unclear what the exact triggers of $\beta$ cell damage and subsequent T1D development are, more is known on the factors regulating the risk of disease development. Family studies have revealed that T1D has a genetic component and it is estimated that around 50\% of the risk for T1D is heritable. Epidemiological studies and research on monozygotic twins have suggested that environmental exposure and epigenetic modifications account for the rest $[1,19,20]$. As reviewed by Jerram and Leslie, it is often hypothesized that genetics determine the predisposition a person has for developing T1D, while the environment provides the trigger for disease onset [19].

Different methods including linkage analyses have been employed in the search for genetic determinants of T1D. Genome-wide association studies (GWAS), which have the power to identify single-nucleotide polymorphisms (SNPs) associated with disease, have revealed around 60 different loci associated with T1D. The contribution of most of these loci to T1D risk is relatively modest (odds ratio $\leq 2.0$ ) [21-23], and for most of the loci, the risk-conferring SNP(s) remain undefined. Many of the GWAS candidate genes have important functions in the immune system and a majority of the genes are also expressed by pancreatic islet cells, including the $\beta$ cells $[24,25]$.

The increasing amount of available SNP data has facilitated the development of algorithms to calculate so-called T1D genetic risk scores (T1D-GRS), which are based on the combination of several risk alleles and by this are able to, with increasing precision, predict who is at risk for developing T1D $[25,26]$. Even better predictions are achieved when the T1D-GRS is combined with non-genetic information such as autoantibody positivity, body mass index and age [26, 27].

\section{Virus Infections as Triggers of $\beta$ Cell Autoimmunity and T1D}

Various environmental factors including dietary components, infections and gut microbial composition have been studied in relation to T1D development [28]. Among infectious agents, viral infections and in particular those from the enterovirus family have been identified as likely triggers of the disease $[29,30]$. Several studies have reported a temporal association between respiratory infections and the appearance of autoantibodies [31, 32, 33•, 34•]. Moreover, a recent meta-analysis showed a significant association between infection with any type of virus during pregnancy and T1D development during childhood [35]. Yet another meta-analysis revealed a clear association between enterovirus infections and either islet autoimmunity or T1D [36]. Given that most viral infections will trigger the production of interferons (IFNs) [37], it is also of interest to mention that two independent studies have reported that the appearance of autoantibodies is preceded by a socalled IFN-related gene transcriptional signature in blood $[38,39]$. Many additional observations have suggested a link between enterovirus infections and the appearance of islet autoantibodies or T1D (for extensive reviews, see [29, 30]), including studies showing that children newly diagnosed with T1D are more frequently seropositive for enteroviral RNA than healthy controls [40-42] and reports suggesting that enterovirus infection in the gut is more common in patients with T1D [43] or children with islet autoimmunity [44].

In addition to these observations, enterovirus proteins have been found in the human T1D pancreas at disease onset by immunohistochemistry and mass spectrometry [45, 46•, 47], and islets isolated from newly diagnosed T1D patients express IFN-stimulated genes [48•], with the latter being a potential indication of a viral infection [49•].

The epidemiological evidence and case studies are also supported by in vitro. experiments and proof-of-concept 
studies in animal models. For example, pancreatic $\beta$ cells express several receptors used by enteroviruses to enter cells $\left[50^{\bullet}, 51\right]$ and numerous enterovirus species have been shown to infect and have cytopathic effects in pancreatic $\beta$ cells [51-53]. Also, Coxsackie B viruses (CVBs) can trigger disease in genetically permissive SOCS-1-tg animals [52] and accelerate the development of T1D in non-obese diabetic (NOD) mice [54, 55].

It should also be noted that some questions exist regarding the role of enterovirus infections in T1D. For example, countries with higher frequency of enterovirus infections seem to have a lower incidence of T1D. Moreover, certain developed countries report a rising incidence of T1D each year [2], despite no increases in the number of enteroviral infections with enterovirus [56]. In addition, some virus serotypes have been directly correlated with a reduced risk of developing T1D [57]. Besides these epidemiological observations, some critique has also been brought forward as to the usefulness of certain methodological tools used to detect viruses in the pancreata at disease onset and in long-standing T1D cases $[58,59]$. Finally, not all studies have been able to confirm the presence of increased levels of enteroviruses in the human T1D gut [60].

Despite these issues, there is ample support for a role for virus infections in T1D [31, 32, 33•, 34•, 61], with evidence suggesting that infections with enterovirus species are capable of triggering $\beta$ cell autoimmunity in predisposed individuals [36]. From the data that has been published on examining the link or missing link between enterovirus infections and T1D, a reasonable conclusion is perhaps that enterovirus infections contribute to some but not all cases of T1D.

\section{Enteroviruses}

Enteroviruses are small single-stranded RNA viruses that are common all over the world. Although some species are known to cause serious diseases, most infections do not lead to severe symptoms in the general population. Examples of enteroviruses include Coxsackievirus A (CVA) and CVB, echoviruses, rhinoviruses, enterovirus 71 (EV71), and poliovirus $[62,63]$. Enteroviruses typically spread via the fecal-oral route and from contaminated surfaces, although some viruses, including the rhinoviruses, spread via respiratory droplet aerosols and direct person-to-person contact. Shedding of the virus in stool can occur for weeks, even in asymptomatic individuals [64].

The key to survival following an enterovirus infection is an intact innate immune response, with the early production of type I IFNs being of critical importance (reviewed in [37]). IFNs are important pro-inflammatory cytokines that induce production of IFN-stimulated gene (ISG) products rendering the cell less permissive to infection. Studies in knockout animals have shown the importance of numerous ISGs with direct or indirect antiviral activity that prevent early virus replication and dissemination prior to the activation of the adaptive immune response. In addition, IFNs upregulate antigen presentation by human leucocyte antigen (HLA) class I and induce the production of chemokines that attract immune cells (reviewed in [37]). Neutralizing antibodies, which appear early in the disease process and persist for life, are essential for viral clearance and long-term immunity (e.g., [65]). CD4+ T cells are likely to be of importance for initiating an adequate antibody response, but the exact role(s) of $\mathrm{CD} 8+\mathrm{T}$ cells remain to be defined $[66,67]$.

\section{From Association to Functional Insight in the Post-GWAS Era: Gene-Environment Interaction Studies, with Focus on Genes with Polymorphisms that Predispose to T1D}

Gene-environment interaction studies aim to describe how genetic and environmental factors jointly influence the risk of developing a certain disease. They can also provide insights as to how certain SNPs affect the host response to infection both at the cellular and organism level. In relation to T1D and for the identification of individuals developing T1D with a possible enteroviral etiology, it may among other be useful to identify loci/SNPs that increase the risk of infection, enterovirus-induced inflammation, and/or enteroviral persistence. These studies may also reveal mechanisms that are central to disease pathogenesis and moreover provide measures to identify individuals who are likely to be at increased risk for developing virus-triggered or virus-accelerated T1D, allowing them to benefit from a preventive virus vaccine or antiviral treatment.

In this review, we describe several T1D risk genes that could be of interest in the context of virus-associated T1D development. To assist in identifying such genes, we compiled a disease-related gene list from GWAS data and an immunogenetic web resource through NHGRI-EBI Catalog [21] and ImmunoBase (https://www.immunobase.org/), respectively. Thereafter, we manually curated this list of genes to include immunologically relevant gene entries, which altogether resulted in a total of 118 genes. These genes could mainly be categorized under Gene Ontology (GO) pathways related to immune system processes, such as activation, proliferation, and signaling of immune cells, reflecting the autoimmune nature of the disease (Fig. 1a). We selected one of the major GO terms, GO:0002376 ("Immune system process"), which showed a highly significant enrichment in gene set enrichment analysis (had the second highest adjusted $p$ value of all GO terms) and was among the terms that were comprised of the highest number of genes (46 genes in total). By this, we narrowed down our selection to these 46 genes and searched 
Fig. 1 Gene Ontology (GO) and KEGG pathway analysis of T1Drelated genes. a 118 genes obtained via the NHGRI-EBI

Catalog and ImmunoBase were subjected to GO pathway overrepresentation analysis ("GO biological process") using the program g:Profiler (Reimand et al., NAR, 2007) with default settings at Benjamini-Hochberg FDR of 0.05 . The graph depicts the top $20 \mathrm{GO}$ Slim categories (holding at least 1000 gene annotations) selected according to the lowest adjusted $p$ value (p.adj). The genes categorized under GO:0002376 were used in the literature search to identify their involvement in viral infections and further subjected to KEGG pathway analysis (using $\mathrm{g}$ :Profiler) to gain a refined overview of their immune-related biological role. b The Circos plot depicts 23/46 of the genes (denoted with gray boxes) under GO:0002376 that had a KEGG pathway assigned (colored boxes). Graphs generated using the ggplot2 [143] and GOplot [144] packages in $R$, images modified using Inkscape 0.92 software a

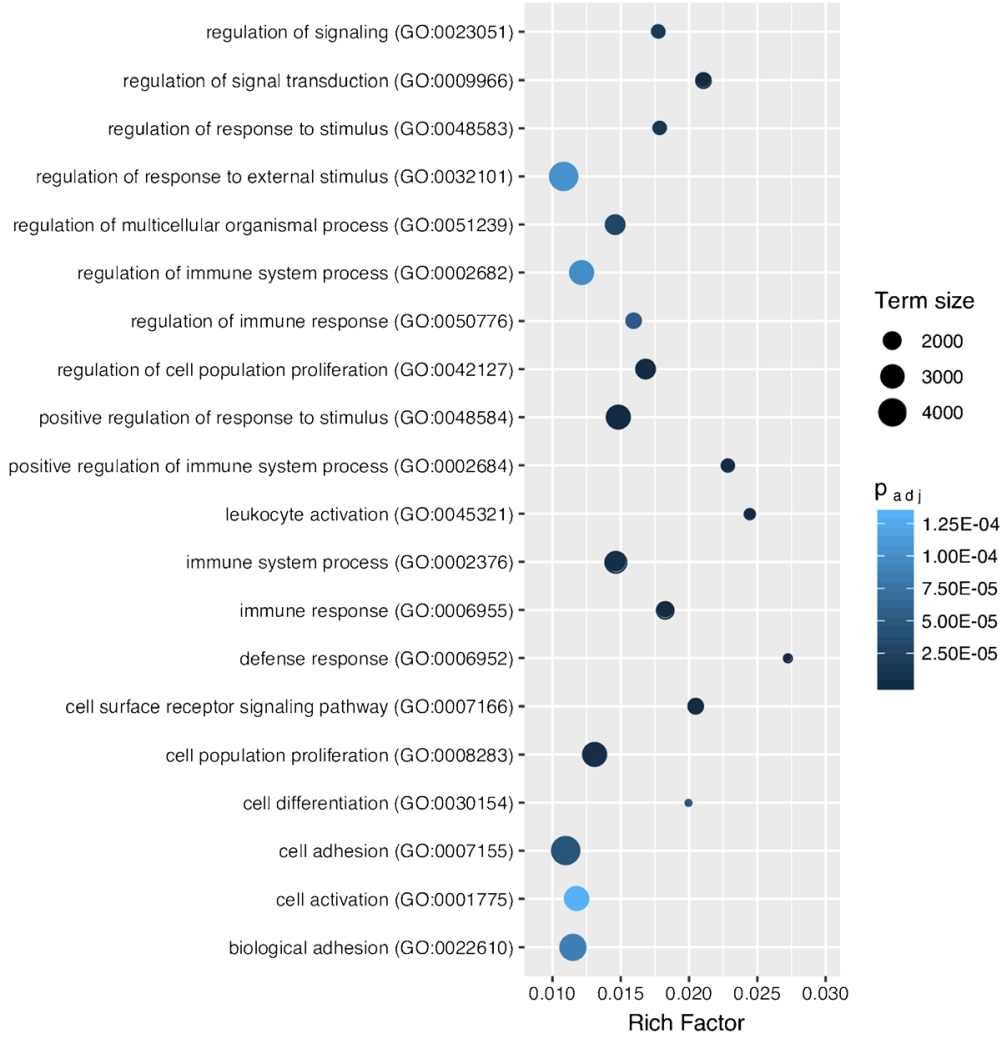

b

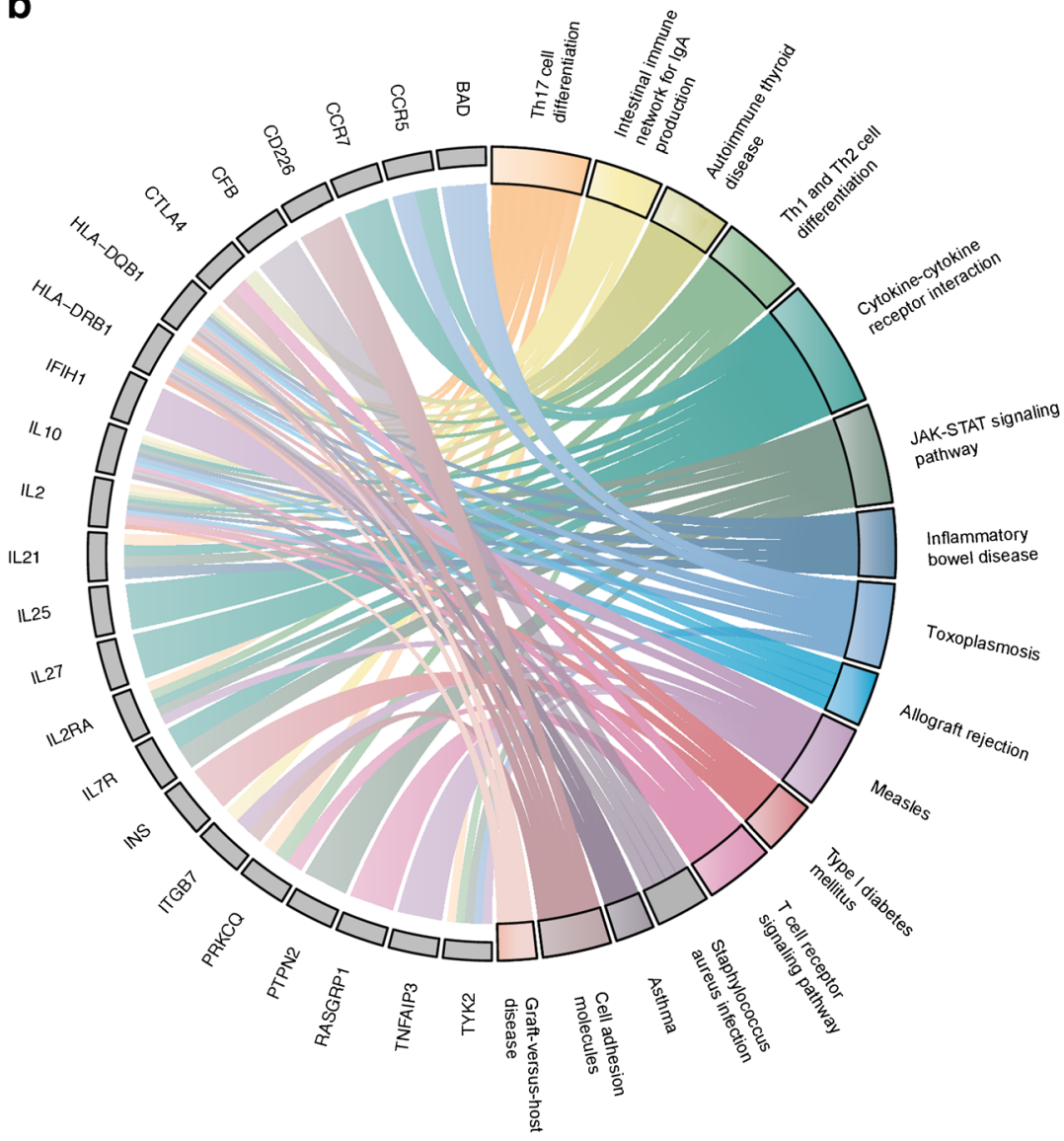


for published data implicating their involvement in viral infections. By retrieving published studies from the PubMed database (using the "virus OR enterovirus OR Coxsackievirus" search terms), we were able to identify that 36 of the 46 genes were related to viral infections, 15 of which had a connection to enterovirus-associated disease development and 13 being specifically associated with Coxsackievirus-related disease pathogenesis (Table 1). KEGG pathway analysis provided a glimpse of the biological pathways that several of the 36 genes are involved in (Fig. 1b). As there seems to be a broader viral element in T1D disease initiation and progression than merely the enterovirus component [31, 32, 33•, 34•, 35], we aimed to provide an overview of a selected number of genes with published virus-associated disease phenotypes and discuss their potential involvement in T1D.

\section{HLA class I and II}

HLA class I and II molecules are involved in antigen presentation to CD8+ and CD4+ T cells, respectively. Little is known about the relationship between HLA class I risk alleles and enterovirus infection. Some enteroviruses have been shown to directly down regulate HLA class I on the surface of infected cells, thereby protecting them from recognition by $\mathrm{CD} 8+\mathrm{T}$ cells [68-70]. Whether different HLA class I allelic variants exhibit a different level of sensitivity to this mechanism remains to be established. Individuals carrying the T1D low-risk allele $\mathrm{B} * 5701$ have been reported to have very low risk for progression of HIV-infection to AIDS (so-called elite controllers) [71]. Whether certain HLA class I alleles could provide similar protection from infections caused by viruses associated with T1D remains to be investigated.

The strongest risk for T1D has been attributed to HLA class II genes [20]. Multiple attempts have been made to connect HLA class II risk alleles to enterovirus infections [72-76]. Most groups have found no association between risk haplotypes and the presence of enteroviral RNA or neutralizing antibodies in the blood or stool, although one study has reported higher levels of anti-enterovirus antibodies in children bearing an HLA-DR risk allele, as compared to children that had a protective haplotype [77]. A review by Zhou and Jensen suggests that the mechanism behind the pathogenicity of HLA-DQ alleles is based on a higher affinity to a broad range of selfantigens [78]. A similar hypothesis was proposed by Marttila et al., who found that T cells derived from T1D patients with the high-risk allele DQB1*0302 responded to a broader range of viral epitopes compared to other patients [79]. Another risk allele, HLA-DR4, was found to be associated with a hyperresponsiveness of T cells to CVB4 antigens in vitro in cursive [80]. In contrast, Ellis et al. found no difference in binding of a common CVB4 epitope to HLA molecules derived from different alleles [81]. Hence, more research is needed to clarify the role of both HLA class I and II in enterovirus infections in humans.

\section{IFIH1 (MDA5)}

IFN induced with helicase C domain 1 (IFIH1) encodes the cytoplasmic pattern recognition receptor (PRR) melanoma differentiation-associated protein 5 (MDA5), which is a component of the innate immune system that recognizes doublestranded RNA (dsRNA). Upon detecting dsRNA, a hallmark of enterovirus replication, MDA5 initiates a signaling pathway that ultimately leads to the activation of the transcription factors NF-KB and IRF3, the transcription of and the subsequent production of type I IFNs [82]. Experimental studies have shown that MDA5 is an IFN-inducible gene (e.g., [83]) and an essential PRR for the detection of enterovirus infections [84, 85].

GWAS studies have identified common and rare gene variants of $I F I H 1$, which regulate risk for T1D development [86, 87]. Consequently, many studies have investigated the functional aspect of IFIH1 in T1D and also in enterovirus infections [82]. For example, two case-control studies found that IFIH1 expression in peripheral blood cells was increased in T1D patients with risk variants of $I F I H 1$, as compared to healthy controls and individuals without the risk allele [88]. Individuals heterozygous for the rs1990760 SNP, a common nonsynonymous SNP which has been strongly associated

Table 1 T1D-associated risk genes with a documented association with virus-associated traits

\begin{tabular}{|c|c|c|c|c|c|c|c|c|}
\hline BAD & BTNL2 & CCR5 & CCR7 & CD226 & CFB & CLEC2D & COLEC10 & CTLA4 \\
\hline CTSH & GAB3 & GPR183 & HLA-DQB1 & HLA-DRB1 & IFIH1 & IKZF1 & IL10 & IL2 \\
\hline IL21 & IL25 & IL27 & IL2RA & IL7R & INS & ITGB7 & MAPT & NCR3 \\
\hline ORMDL3 & PGM1 & PLEKHA1 & PRKCQ & PRKD2 & PTPN2 & PTPN22 & RAC2 & RASGRP1 \\
\hline SH2B3 & SIRPG & SKAP2 & TAP2 & TNFAIP3 & TRIM31 & TYK2 & UBASH3A & UMOD \\
\hline ZFP36L1 & & & & & & & & \\
\hline
\end{tabular}

Overview of genes within the immune system process (GO:0002376) term and the presence of virus-related disease pathogenesis. PubMed literature search on the 46 genes within the GO:0002376 term revealed an importance of 36 genes in virus-associated pathogenesis (entries in bold). 15 of those revealed a connection to enterovirus-associated disease development (entries on gray background) with all the aforementioned (except for ORMDL3 and $\mathrm{RAC2}$ ) being specifically indicated in Coxsackievirus disease pathogenesis. 
with altered risk for T1D development, were reported to be more often positive for enteroviral RNA in the blood, although the association was not very strong [89]. A similar study looking at enterovirus levels in the stool found no link with any of the common polymorphisms in IFIH1 [90]. Pang et al. reported no association between the common SNP and the risk for enterovirus infection, but instead found a link with severe EV71 infection, indicating that the SNP may influence host immune response without affecting viral clearance [91]. Jermendy et al. reported that the risk SNP rs1990760 is associated with the seasonality of T1D disease onset, with summer being the season when the proportion of individuals carrying the homozygous risk genotype was highest over the calendar year [92••]. This discovery is interesting considering that summer is also the season when enterovirus infections peak [93].

Experimental studies have shown that mice which lack MDA5 show an increased susceptibility to enteroviral infection and higher mortality than wild-type animals $[84,85]$. In contrast, heterozygous (MDA5+/-) NOD mice expressing lower levels of MDA5 than homozygous (MDA5+/+) NOD mice are protected from virus-induced T1D [94]. A mouse model with a knock-in mutation encoding IFIH $1^{\mathrm{T} 946}$ showed enhanced production of type I IFNs at steady state and improved survival following lethal viral challenge but displayed greatly increased risk for autoimmune disease [95]. In addition, experimental studies have demonstrated that MDA5 encoded by variants of IFIH1 associated with protection from T1D development show loss of function [86, 87]. Collectively, these findings suggest that the presence of MDA5 is required for efficient antiviral defense, but that excess levels of MDA5 (and increased production of IFNs) may contribute to inflammation and autoimmunity.

\section{PTPN22}

Protein tyrosine phosphatase non-receptor type 22 (PTPN22) contains risk polymorphisms that almost double the risk for T1D. PTPN22, also known as Lyp, is a tyrosine phosphatase expressed in hematopoietic cell lineages. PTPN22 plays an inhibitory role in the activation of the immune system by inhibiting $\mathrm{T}$ cell receptor signaling and preventing the expansion of effector T cells [96]. In addition, PTPN22 has been reported to positively regulate TLR-triggered IFN production in myeloid cells [97], suggesting that it contributes both to innate and adaptive immune functions.

The most well-studied polymorphism in PTPN22 is rs2476601, which causes a substitution of an arginine by a tryptophan at position 620 (R620W). This polymorphism has been associated with T1D in most population groups, as well as with other autoimmune diseases. The R620W polymorphism most likely causes a functional change in the PTPN22 protein. Though there is currently no consensus within the field which mechanism underlies the altered risk for autoimmunity in individuals carrying this polymorphism, suggestions have been made that it may be context and/or cell type dependent [96].

Interestingly, a few studies report the involvement of $P T P N 22$ in infections with viruses other than enteroviruses. Wang et al. showed that the rs 2476601 SNP is associated with lower IFN production by macrophages in response to TLR ligand stimulation and suggested that this may result in a weakened antiviral response to infections [97]. Crabtree et al. found that the T1D rs2476601 risk allele is associated with reduced CD4+ T cell response and antibody affinity maturation to influenza vaccination [98]. Maine et al. identified PTPN22 as the key promoter of chronic infection with lymphocytic choriomeningitis virus (LCMV) by suppressing T cell activation [99]. In contrast, Montes-Cano et al. did not observe an effect of the rs2476601 SNP on the outcome of chronic hepatitis C infection [100]. Thus, it could be that by suppressing the function of effector T cells, PTPN22 diminishes response to certain virus types, allowing the establishment of a persistent infection. However, the suppressive effect of the rs2476601 on the immune system as proposed by Crabtree et al. [98] is in direct contradiction with the suggested mechanism in T1D, i.e., reduced inhibition of effector T cells or increased suppression of regulatory T cells (Tregs) [96].

The MIDIA study has looked at the relationship between PTPN22 and enterovirus infection [101]. The study had an epidemiological setup, in which a large group of Norwegian children were screened for SNPs in T1D risk alleles. The genotypes were then correlated to the presence of enterovirus in stool samples. Although the rs $2476601 \mathrm{SNP}$ had one of the highest correlations with enterovirus positivity, this association was not strong enough to reach statistical power. Hence, more research is needed to gain better insights into the functional consequences of the rs2476601 SNP and its involvement in T1D and enterovirus infection.

\section{CTLA-4}

Cytotoxic T lymphocyte-associated protein 4 (CTLA-4) encodes the CTLA-4 protein, also known as CD152. CTLA-4 is a molecule that is normally expressed in low levels on CD4+ and CD8+ T cells. CTLA-4 is structurally related to CD28, a stimulatory molecule that contributes to effector $T$ cell activation by binding the $\mathrm{B} 7$ ligand expressed on antigenpresenting cells (APCs). This binding is necessary for the activation to occur. CTLA-4 competes with CD28 for B7 molecules, and high expression of CTLA-4 leads to inhibition of $T$ cell activation [102].

A few studies have been published on the connection between CTLA-4 and enterovirus infections. Thus, a study by Yang et al. found an association between a T1D risk associated SNP in CTLA-4 (rs231775) and the likelihood of developing severe meningoencephalitis after infection with EV71 
[103]. A similar finding was done by Han et al., who showed that the administration of CTLA-4 fusion protein attenuated Coxsackievirus B3-induced myocarditis in mice [104]. Since viral myocarditis is for a large part caused by excessive inflammation rather than virus-induced cytopathology [105], both studies are suggestive that CTLA- 4 mostly affects the immune response to the pathogen rather than the viral entry or replication. These observations together with the demonstration that T1D-related CTLA4 polymorphisms are linked to increased IFN- $\gamma$ production by peripheral blood mononuclear cells in response to a broad range of different antigens, including CVB4 [106], suggest that autoimmunity associated SNPs in CTLA4 are coupled with impaired immunoregulation, which may elevate the risk for immunopathology during enterovirus infection.

\section{IL10}

The interleukin-10 gene (IL10) encodes the cytokine IL-10, which is produced predominantly by Tregs and has an antiinflammatory effect [107]. SNPs in the ILI0 gene region have been identified in GWAS studies as risk factors for T1D [23].

It has been reported that infections with CVB3 and CVB4 are associated with increased IL-10 production [108-111]. A similar association has also been described for EV71 [112-114]. The relationship between SNPs in the IL10 gene region and infections with enterovirus has also been examined in several studies. The rs $1800896 \mathrm{SNP}$ - a nucleotide substitution upstream of the ILIO gene- - has been associated with various inflammatory diseases, including autoimmune liver disease [115] and systemic lupus erythematosus [116], and is strongly correlated with susceptibility to EV71 infections in Chinese children [117]. Another SNP in the promoter region of IL10, rs1800872, was found to increase the risk of EV71caused hand, foot, and mouth disease [118].

Several studies suggest that IL-10 may promote viral persistence [107]. For instance, Yeung et al. found that children positive for enteroviral RNA usually had elevated serum levels of IL-10. However, this did not correlate with their T1D status [119]. Furthermore, an experimental study showed that IL-10 production was induced in mice upon infection with CVB and appeared to facilitate the development of chronic pancreatitis, as IL-10 knockout animals resolved the acute pancreatitis [120].

\section{TNFAIP3}

TNF-alpha-induced protein 3 (TNFAIP3), also known as A20, is a cytoplasmic protein which mainly exerts antiinflammatory function by inhibiting NF-KB activation [121]. SNPs in TNFAIP3 have been associated with multiple autoimmune diseases, including T1D [23]. Even prior to GWAS, TNFAIP3 was identified as a T1D risk allele, and in vitro studies discovered that A20 expression can be induced in $\beta$ cells to protect them from cytokine-induced apoptosis. A subsequent animal study reported that genetic therapy with A20 could protect against T1D in a streptozotocin-induced T1D mouse model [121]. In 2016, Fukaya et al. reported that the noncoding rs 2327832 polymorphism in TNFAIP3 is associated with reduced residual $\beta$ cell function and impaired glycemic control in children with T1D [122]. This same polymorphism was later confirmed to have an association with a higher susceptibility to T1D in a large cohort [123].

Very little research has examined the role of A20 in enterovirus infections. It has been reported that A20 ameliorates CVB3-induced myocarditis by inhibiting NF- $\mathrm{KB}$ signaling [124]. Interestingly, Doukas et al. reported that TNFAIP3 is one of the few genes that escape transcriptional shutoff by the poliovirus. In addition, the authors report that depletion of A20 leads to increased virus replication [125]. In contrast, some other virus types (e.g., influenza A), profit from high A20 expression, since they can inhibit the expression of type I IFNs $[126,127]$.

\section{Interleukin-21 and IL-2}

The interleukin-21 (IL21) gene encodes IL-21, a cytokine that is mainly produced by T cells and natural killer T cells [128]. It acts on both lymphoid and myeloid cells, and has been associated with positive and negative immune regulation depending on the context. The IL21 locus is shared with the interleukin-2 (IL2) gene, encoding a cytokine that is involved in the activation of effector $\mathrm{T}$ cells and in the generation, homeostasis, and function of Tregs [129]. Both genes have been shown to play a role in autoimmunity; IL-21 by promoting $\mathrm{T}$ follicular helper- ( $\mathrm{Tfh}$ ) and Th17 cell differentiation, and by inhibiting Treg generation, and IL-2 via altered Treg function and homeostasis [130-132].

As shown by Yeung et al., children infected with enteroviruses generally have lower serum concentration of IL-21 than those that are not infected, although this did not correlate with their T1D autoantibody status (i.e., prediabetic or healthy) [119]. Another study investigated IL-21 signaling in the context of CVB3-induced myocarditis and concluded that IL-21 mediate excessive activation of CD8+ T cells, thereby contributing to inflammation [133]. Importantly, the increase in effector $\mathrm{T}$ cells does not lead to a reduced virus titer, which is rather indicative of a hyper-reactive immune system without increased functionality. Consistent with this finding, mice deficient in the IL-21 receptor display lower inflammation of the myocardium and fewer autoreactive B cells, lowering tissue damage in virus-induced myocarditis [134].

IL2, the second gene in the IL-21 gene cluster, is predominantly expressed in activated T cells. IL-2 binds to its receptor, IL-2R, and stimulates proliferation of both effector and regulatory T cells [129]. GWAS studies have also identified 
T1D associated SNPs in the $I L-2 R A$ gene and linked them to altered IL-2R signaling in Tregs [131]. Serum IL-2 levels do not differ between T1D and healthy controls [135], but it has been reported that they are elevated in severe EV71-induced hand, foot, and mouth disease [136]. In viral myocarditis, IL-2 has been shown to play a dual role, contributing to improved viral clearance during the acute phase and prolonging inflammation during the chronic phase [137].

\section{Implications of Gene-Environment Interaction Studies}

GWAS have already revealed many important aspects of T1D etiology. With the emergence of genome-editing techniques, we have entered the post-genomic era with the possibility to introduce specific changes into cell lines and primary cells, study the independent and combined effect(s) of SNPs on biological functions, and also identify causal SNPs. Such efforts may also provide insight into mechanisms that are central to virus-triggered T1D and facilitate the search for therapeutic targets.

Insights gained from gene-environment interaction studies coupled with further genetic studies on phenotypically defined subgroups of T1D patients may also assist in refining the current T1D-GRS, and perhaps even more importantly, open the option of stratification of individuals based on disease endotypes. For this to become a reality, further insights into the genetic, as well as nongenetic, determinants of disease heterogeneity may be needed. Moreover, we may need to consider that genes and environmental factors of importance for the triggering events (i.e., induction of islet autoimmunity) may not be the same as those involved in precipitating disease in already autoantibody-positive individuals (i.e. clinical disease development). For the identification of an endotype with an enteroviral etiology, we also need to learn more about when and how the virus contributes to the disease. While the occurrence of virus in the pancreas at disease onset has led to the hypothesis that the virus causes a persistent infection in the islets, it is as of yet unclear whether unresolved infections, acute infections, or both are accountable for the reported link between enterovirus infection and T1D.

Another aspect to consider for the development of GRS is population diversity. Currently, most of the GWAS studies have been performed in the Caucasian populations living in Europe or North America. We are just in the beginning of understating how translatable the GRS are to other regions in the world, or even to other ethnicities living in Europe or North America [138]. Beyond this, and to further improve the precision of the GRS, genome-wide association interaction studies (GWAIS) will most likely be required to unravel functional relationships between genes (epistasis) [139].

Among the non-genetic factors to be taken into account when calculating risk for T1D development, age may be of importance as twin studies for example have indicated that the heritable risk component declines with age [140]. For predicting T1D with an enteroviral etiology, gender may also play a small, yet non-negligible role [41].

Due to these additional layers of complexity, SNP genotyping and calculation of GRS might not prove to be a feasible strategy for predicting the absolute risk of developing T1D, although it might be useful for risk assessment and patient stratification in case-control studies and clinical trials. Hence, these measures could also be used to stratify prediabetic individuals who would benefit from receiving an enterovirus vaccine, or dividing recent onset T1D patients into subgroups that would be more or less likely to respond favorably to antiviral therapy. Enterovirus infections could be treated with antivirals and many efforts are being made to develop broadly acting antivirals (reviewed in [62, 129]). While a vaccine against enteroviruses suspected to play a role in triggering T1D is not yet available, prototype vaccines against CVBs have shown excellent safety, immunogenicity, and efficacy in preventing infection and enterovirus-associated disease $[54,141,142 \cdot]$.

\section{Conclusions}

This review summarizes current knowledge surrounding the relationship between enterovirus infections and T1D, with a special focus on T1D genetic risk alleles in genes related to the host immune system and their possible role in altering susceptibility to virus infection or the magnitude of the host antiviral immune response. It is evident that these types of study have so far been limited in number and few have examined the direct interactions between T1D-associated genes/ SNPs and the outcome of enterovirus infections. The studies cited do not support that SNPs in the genes which have been reviewed are increasing susceptibility to infection, more often they seem to either decrease the risk for infection or favor the establishment of viral persistence. This fits well with the chronic nature of islet autoimmunity. The studies also point to the fact that several T1D-associated genes modulate the immune response to virus infection. Indeed, several risk variants appear to predispose the immune system towards hyper-reactivity, which may manifest itself upon encounter with an exogenous pathogen, such as an enterovirus, and thereby trigger autoimmunity.

Further research in this area will provide additional insights into the etiology and pathogenesis of T1D. This may 
not only assist in defining therapeutic targets, but also provide measures to identify individuals at risk-such studies can be translated into clinically useful advances in the personalization of T1D prevention by providing genetic markers useful for patient stratification and the selection of $\operatorname{method}(\mathrm{s})$ for disease prevention.

Acknowledgements We would like to acknowledge Dr. Virginia Stone for discussion and critical reading of the manuscript. The M.F-T. laboratory is financially supported by Karolinska Institutet including the Strategic Research Program in Diabetes, the Swedish Research Council, the Swedish Child Diabetes Foundation, the Swedish Heart and Lung Foundation, the Novo Nordisk Foundation, a JDRF strategic research agreement (3-SRA-2017-492-A-N) to the network of Pancreatic Organ Donors-Virus (nPOD-V) consortium.

Funding Information Open access funding provided by Karolinska Institutet.

\section{Compliance with Ethical Standards}

Conflict of Interest Marfa Blanter and Helena Sork declare that they have no conflict of interest.

Soile Tuomela reports a Novo Nordisk Postdoctoral Research Fellowship and is an inventor on the patent WO/2014/207312.

Malin Flodström-Tullberg reports grants from Janssen, and personal fees from Provention Bio Inc. (which is developing an enterovirus vaccine) where she serves on the scientific advisory board.

Human and Animal Rights and Informed Consent All reported studies/ experiments with human or animal subjects performed by the authors have been previously published and compiled with all applicable ethical standards (including the Helsinki Declaration and its amendments, institutional/national research committee standards, and international/national/institutional guidelines).

Open Access This article is distributed under the terms of the Creative Commons Attribution 4.0 International License (http:// creativecommons.org/licenses/by/4.0/), which permits unrestricted use, distribution, and reproduction in any medium, provided you give appropriate credit to the original author(s) and the source, provide a link to the Creative Commons license, and indicate if changes were made.

\section{References}

Papers of particular interest, published recently, have been highlighted as:

- Of importance

•- Of major importance

1. DiMeglio LA, Evans-Molina C, Oram RA. Type 1 diabetes. Lancet. 2018;391(10138):2449-62. https://doi.org/10.1016/ s0140-6736(18)31320-5.

2. Patterson CC, Harjutsalo V, Rosenbauer J, Neu A, Cinek O, Skrivarhaug Rami-Merhar B, Soltesz G, Svensson J, Parslow RC, Castell C, Schoenle EJ, Bingley PJ, Dahlquist G, JaroszChobot PK, Marčiulionyte D, Roche EF, Rothe U, Bratina N, Ionescu-Tirgoviste C, Weets I, Kocova M, Cherubini V, Rojnic
Putarek N, deBeaufort CE, Samardzic M, Green A, et al. Trends and cyclical variation in the incidence of childhood type 1 diabetes in 26 European centres in the 25 year period 1989-2013: a multicentre prospective registration study. Diabetologia. 2019;62(3):408-17. https://doi.org/10.1007/s00125-018-4763-3.

3. Wilson V. Diagnosis and treatment of diabetic ketoacidosis. Emerg Nurse. 2012;20(7):14-8. https://doi.org/10.7748/en2012. 11.20.7.14.c9405.

4. Bjornstad P, Snell-Bergeon JK, Nadeau KJ, Maahs DM. Insulin sensitivity and complications in type 1 diabetes: new insights. World $\mathrm{J}$ Diabetes. 2015;6(1):8-16. https://doi.org/10.4239/wjd.v6.i1.8.

5. Gubitosi-Klug RA, Braffett BH, White NH, Sherwin RS, Service FJ, Lachin JM, Tamborlane WV, et al. the Diabetes Control and Complications Trial (DCCT)/Epidemiology of Diabetes Interventions and Complications (EDIC) Research Group Risk of severe hypoglycemia in type 1 diabetes over 30 years of follow-up in the DCCT/EDIC study. Diabetes Care. 2017;40(8):1010-6. https:// doi.org/10.2337/dc16-2723.

6. Richardson SJ, Rodriguez-Calvo T, Gerling IC, Mathews CE, Kaddis JS, Russell MA, et al. Islet cell hyperexpression of HLA class I antigens: a defining feature in type 1 diabetes. Diabetologia. 2016;59(11):2448-58. https://doi.org/10.1007/s00125-016-4067-4. Study examining pancreas specimens from three different organ collections for the expression of HLA class I and demonstrating that HLA class I is hyperexpressed in T1D

7. Russell MA, Redick SD, Blodgett DM, Richardson SJ, Leete P, Krogvold L, Dahl-Jørgensen K, Bottino R, Brissova M, Spaeth JM, Babon JAB, Haliyur R, Powers AC, Yang C, Kent SC, Derr AG, Kucukural A, Garber MG, Morgan NG, Harlan DM, et al. HLA class II antigen processing and presentation pathway components demonstrated by transcriptome and protein analyses of islet beta-cells from donors with type 1 diabetes. Diabetes. 2019;68(5):988-1001. https:// doi.org/10.2337/db18-0686.

8. Willcox A, Richardson SJ, Bone AJ, Foulis AK, Morgan NG. Analysis of islet inflammation in human type 1 diabetes. Clin Exp Immunol. 2009;155(2):173-81. https://doi.org/10.1111/j. 1365-2249.2008.03860.x.

9. Krogvold L, Wiberg A, Edwin B, Buanes T, Jahnsen FL, Hanssen KF, Larsson E, Korsgren O, Skog O, Dahl-Jørgensen K, et al. Insulitis and characterisation of infiltrating $T$ cells in surgical pancreatic tail resections from patients at onset of type 1 diabetes. Diabetologia. 2016;59(3):492-501. https://doi.org/10.1007/ s00125-015-3820-4.

10. Campbell-Thompson M, Fu A, Kaddis JS, Wasserfall C, Schatz DA, Pugliese A, Atkinson MA, et al. Insulitis and beta-cell mass in the natural history of type 1 diabetes. Diabetes. 2016;65(3): 719-31. https://doi.org/10.2337/db15-0779.

11. Arif S, Leete P, Nguyen V, Marks K, Nor NM, Estorninho M, Kronenberg-Versteeg D, Bingley PJ, Todd JA, Guy C, Dunger DB, Powrie J, Willcox A, Foulis AK, Richardson SJ, de Rinaldis E, Morgan NG, Lorenc A, Peakman M, et al. Blood and islet phenotypes indicate immunological heterogeneity in type 1 diabetes. Diabetes. 2014;63(11):3835-45. https://doi.org/10. 2337/db14-0365.

12. Leete P, Willcox A, Krogvold L, Dahl-Jorgensen K, Foulis AK, Richardson SJ, et al. Differential insulitic profiles determine the extent of beta-cell destruction and the age at onset of type 1 diabetes. Diabetes. 2016;65(5):1362-9. https://doi.org/10.2337/db15-1615.

13. Oram RA, Sims EK, Evans-Molina C. Beta cells in type 1 diabetes: mass and function; sleeping or dead? Diabetologia. 2019;62(4):567-77. https://doi.org/10.1007/s00125-019-4822-4. Excellent review on the pancreatic $\beta$ cell in T1D.

14. Keenan HA, Sun JK, Levine J, Doria A, Aiello LP, Eisenbarth G, et al. Residual insulin production and pancreatic ss-cell turnover after 50 years of diabetes: Joslin Medalist Study. Diabetes. 2010;59(11):2846-53. https://doi.org/10.2337/db10-0676. 
15. Rodriguez-Calvo T, Suwandi JS, Amirian N, Zapardiel-Gonzalo J, Anquetil F, Sabouri S, et al. Heterogeneity and lobularity of pancreatic pathology in type 1 diabetes during the prediabetic phase. J Histochem Cytochem. 2015;63(8):626-36. https://doi.org/10.1369/ 0022155415576543.

16. Campbell-Thompson M, Rodriguez-Calvo T, Battaglia M. Abnormalities of the exocrine pancreas in type 1 diabetes. Curr Diab Rep. 2015;15(10):79. https://doi.org/10.1007/s11892-0150653-y.

17. Campbell-Thompson ML, Kaddis JS, Wasserfall C, Haller MJ, Pugliese A, Schatz DA, et al. The influence of type 1 diabetes on pancreatic weight. Diabetologia. 2016;59(1):217-21. https:// doi.org/10.1007/s00125-015-3752-z.

18. Campbell-Thompson ML, Filipp SL, Grajo JR, Nambam B, Beegle $\mathrm{R}$, Middlebrooks $\mathrm{EH}$, et al. Relative pancreas volume is reduced in first-degree relatives of patients with type 1 diabetes. Diabetes Care. 2019;42(2):281-7. https://doi.org/10.2337/dc18-1512.

19. Jerram S, Leslie RD. The genetic architecture of type 1 diabetes. Genes. 2017;8(8). https://doi.org/10.3390/genes8080209.

20. Redondo MJ, Jeffrey J, Fain PR, Eisenbarth GS, Orban T. Concordance for islet autoimmunity among monozygotic twins. N Engl J Med. 2008;359(26):2849-50. https://doi.org/10.1056/ NEJMc0805398.

21. Buniello A, MacArthur JAL, Cerezo M, Harris LW, Hayhurst J, Malangone C, et al. The NHGRI-EBI GWAS catalog of published genome-wide association studies, targeted arrays and summary statistics 2019. Nucleic Acids Res. 2019;47(D1):D1005-D12. https://oi.org/10.1093/nar/gky1120.

22. Nyaga DM, Vickers MH, Jefferies C, Perry JK, O'Sullivan JM. The genetic architecture of type 1 diabetes mellitus. Mol Cell Endocrinol. 2018;477:70-80. https://doi.org/10.1016/j.mce.2018.06.002.

23. Rich SS. Genetics and its potential to improve type 1 diabetes care. Curr Opin Endocrinol Diabetes Obes. 2017;24(4):279-84. https:// doi.org/10.1097/MED.0000000000000347.

24. Eizirik DL, Sammeth M, Bouckenooghe T, Bottu G, Sisino G, Igoillo-Esteve $\mathrm{M}$, et al. The human pancreatic islet transcriptome: expression of candidate genes for type 1 diabetes and the impact of pro-inflammatory cytokines. PLoS Genet. 2012;8(3):e1002552. https://doi.org/10.1371/journal.pgen.1002552.

25. Brorsson CA, Nielsen LB, Andersen ML, Kaur S, Bergholdt R, Hansen L, et al. Genetic risk score modelling for disease progression in new-onset type 1 diabetes patients: increased genetic load of islet-expressed and cytokine-regulated candidate genes predicts poorer glycemic control. J Diabetes Res. 2016;2016:9570424-8. https://doi.org/10.1155/2016/9570424.

26. Oram RA, Patel K, Hill A, Shields B, McDonald TJ, Jones A, et al. A type 1 diabetes genetic risk score can aid discrimination between type 1 and type 2 diabetes in young adults. Diabetes Care. 2016;39(3):337-44. https://doi.org/10.2337/dc15-1111.

27. Redondo MJ, Geyer S, Steck AK, Sharp S, Wentworth JM, Weedon $\mathrm{MN}$, et al. A type 1 diabetes genetic risk score predicts progression of islet autoimmunity and development of type $1 \mathrm{di}-$ abetes in individuals at risk. Diabetes Care. 2018;41(9):1887-94. https://doi.org/10.2337/dc18-0087.

28. Rewers M, Ludvigsson J. Environmental risk factors for type 1 diabetes. Lancet. 2016;387(10035):2340-8. https://doi.org/10. 1016/s0140-6736(16)30507-4.

29. Richardson SJ, Morgan NG. Enteroviral infections in the pathogenesis of type 1 diabetes: new insights for therapeutic intervention. Curr Opin Pharmacol. 2018;43:11-9. https://doi.org/10. 1016/j.coph.2018.07.006.

30. Rodriguez-Calvo T. Enteroviral infections as a trigger for type 1 diabetes. Curr Diab Rep. 2018;18(11):106. https://doi.org/10. 1007/s11892-018-1077-2.

31. Rasmussen T, Witso E, Tapia G, Stene LC, Ronningen KS. Selfreported lower respiratory tract infections and development of islet autoimmunity in children with the type 1 diabetes high-risk HLA genotype: the MIDIA study. Diabetes Metab Res Rev. 2011;27(8): 834-7. https://doi.org/10.1002/dmrr.1258.

32. Beyerlein A, Wehweck F, Ziegler AG, Pflueger M. Respiratory infections in early life and the development of islet autoimmunity in children at increased type 1 diabetes risk: evidence from the BABYDIET study. JAMA Pediatr. 2013;167(9):800-7. https:// doi.org/10.1001/jamapediatrics.2013.158.

33. Beyerlein A, Donnachie E, Jergens S, Ziegler AG. Infections in early life and development of type 1 diabetes. JAMA. 2016;315(17):1899-901. https://doi.org/10.1001/jama.2016. 2181. This study shows that respiratory tract infections in young age increase risk for T1D development.

34. Lönnrot M, Lynch KF, Elding Larsson H, Lernmark A, Rewers MJ, Torn C, et al. Respiratory infections are temporally associated with initiation of type 1 diabetes autoimmunity: the TEDDY study. Diabetologia. 2017;60(10):1931-40. https://doi.org/10. 1007/s00125-017-4365-5. This study demonstrates a positive correlation between respiratory infections and increased risk for autoimmunity in young children.

35. Allen DW, Kim KW, Rawlinson WD, Craig ME. Maternal virus infections in pregnancy and type 1 diabetes in their offspring: systematic review and meta-analysis of observational studies. Rev Med Virol. 2018;28(3):e1974. https://doi.org/10.1002/rmv.1974.

36. Yeung WC, Rawlinson WD, Craig ME. Enterovirus infection and type 1 diabetes mellitus: systematic review and meta-analysis of observational molecular studies. Bmj. 2011;342:d35.

37. Lind K, Huhn MH, Flodstrom-Tullberg M. Immunology in the clinic review series; focus on type 1 diabetes and viruses: the innate immune response to enteroviruses and its possible role in regulating type 1 diabetes. Clin Exp Immunol. 2012;168(1):30-8. https://doi.org/10.1111/j.1365-2249.2011.04557.x.

38. Ferreira RC, Guo H, Coulson RM, Smyth DJ, Pekalski ML, Burren OS, et al. A type I interferon transcriptional signature precedes autoimmunity in children genetically at risk for type 1 diabetes. Diabetes. 2014;63(7):2538-50. https://doi.org/10.2337/db13-1777.

39. Kallionpaa H, Elo LL, Laajala E, Mykkanen J, Ricano-Ponce I, Vaarma M, et al. Innate immune activity is detected prior to seroconversion in children with HLA-conferred type 1 diabetes susceptibility. Diabetes. 2014;63(7):2402-14. https://doi.org/10.2337/db13-1775.

40. Lönnrot M, Salminen K, Knip M, Savola K, Kulmala P, Leinikki $\mathrm{P}$, et al. Enterovirus RNA in serum is a risk factor for beta-cell autoimmunity and clinical type 1 diabetes: a prospective study. J Med Virol. 2000;61(2):214-20.

41. Oikarinen S, Martiskainen M, Tauriainen S, Huhtala H, Ilonen J, Veijola R, et al. Enterovirus RNA in blood is linked to the development of type 1 diabetes. Diabetes. 2011;60(1):276-9. https://doi.org/ 10.2337/db10-0186.

42. Cinek O, Stene LC, Kramna L, Tapia G, Oikarinen S, Witsø E, et al. Enterovirus RNA in longitudinal blood samples and risk of islet autoimmunity in children with a high genetic risk of type 1 diabetes: the MIDIA study. Diabetologia. 2014;57(10):2193-200. https://doi.org/10.1007/s00125-014-3327-4.

43. Oikarinen M, Tauriainen S, Oikarinen S, Honkanen T, Collin P, Rantala I, et al. Type 1 diabetes is associated with enterovirus infection in gut mucosa. Diabetes. 2012;61(3):687-91. https:// doi.org/10.2337/db11-1157.

44. Kim KW, Horton JL, Pang CNI, Jain K, Leung P, Isaacs SR, et al. Higher abundance of enterovirus A species in the gut of children with islet autoimmunity. Sci Rep. 2019;9(1):1749. https://doi.org/ 10.1038/s41598-018-38368-8.

45. Dunne JL, Richardson SJ, Atkinson MA, Craig ME, Dahl-Jorgensen K, Flodstrom-Tullberg M, et al. Rationale for enteroviral vaccination and antiviral therapies in human type 1 diabetes. Diabetologia. 2019;62(5):744-53. https://doi.org/10.1007/s00125-019-4811-7. 
46. Krogvold L, Edwin B, Buanes T, Frisk G, Skog O, Anagandula $\mathrm{M}$, et al. Detection of a low-grade enteroviral infection in the islets of langerhans of living patients newly diagnosed with type 1 diabetes. Diabetes. 2015;64(5):1682-7. https://doi.org/10.2337/ $\mathrm{db} 14-1370$. This study suggests that the pancreatic islets at T1D onset are persistently infected with enterovirus.

47. Richardson SJ, Willcox A, Bone AJ, Foulis AK, Morgan NG. The prevalence of enteroviral capsid protein vp1 immunostaining in pancreatic islets in human type 1 diabetes. Diabetologia. 2009;52(6): 1143-51. https://doi.org/10.1007/s00125-009-1276-0.

48. Lundberg M, Krogvold L, Kuric E, Dahl-Jorgensen K, Skog O. Expression of interferon-stimulated genes in insulitic pancreatic islets of patients recently diagnosed with type 1 diabetes. Diabetes. 2016;65(10):3104-10. https://doi.org/10.2337/db16-0616. Pancreatic islets from recently diagnosed T1D patients show an ISG signature.

49. Domsgen E, Lind K, Kong L, Hühn MH, Rasool O, van Kuppeveld F, et al. An IFIH1 gene polymorphism associated with risk for autoimmunity regulates canonical antiviral defence pathways in Coxsackievirus infected human pancreatic islets. Sci Rep. 2016;6(1). https://doi.org/10.1038/srep39378. A study showing that pancreatic islets infected with CVB3 express IFNstimulated genes and that the islet the type III IFN response is regulated by a common SNP in the IFIH1 gene.

$50 . \bullet$ Ifie E, Russell MA, Dhayal S, Leete P, Sebastiani G, Nigi L et al. Unexpected subcellular distribution of a specific isoform of the Coxsackie and adenovirus receptor, CAR-SIV, in human ancreatic beta cells, Diabetologia 2018;61(11):2344-2355. doi:10.1007/ s00125-018-4704-1. This study shows that human pancreatic $\beta$ cells express an isoform of the Coxsackie and adenovirus receptor (CAR).

51. Ylipaasto P, Klingel K, Lindberg AM, Otonkoski T, Kandolf R, Hovi T, et al. Enterovirus infection in human pancreatic islet cells, islet tropism in vivo and receptor involvement in cultured islet beta cells. Diabetologia. 2004;47(2):225-39. https://doi.org/10.1007/ s00125-003-1297-z.

52. Flodstrom M, Maday A, Balakrishna D, Cleary MM, Yoshimura A, Sarvetnick N. Target cell defense prevents the development of diabetes after viral infection. Nat Immunol. 2002;3(4):373-82.

53. Roivainen M, Ylipaasto P, Savolainen C, Galama J, Hovi T, Otonkoski T. Functional impairment and killing of human beta cells by enteroviruses: the capacity is shared by a wide range of serotypes, but the extent is a characteristic of individual virus strains. Diabetologia. 2002;45(5):693-702. https://doi.org/10. 1007/s00125-002-0805-x.

54. Larsson PG, Lakshmikanth T, Laitinen OH, Utorova R, Jacobson $\mathrm{S}$, Oikarinen $\mathrm{M}$, et al. A preclinical study on the efficacy and safety of a new vaccine against Coxsackievirus B1 reveals no risk for accelerated diabetes development in mouse models. Diabetologia. 2015;58(2):346-54. https://doi.org/10.1007/ s00125-014-3436-0.

55. Serreze DV, Ottendorfer EW, Ellis TM, Gauntt CJ, Atkinson MA. Acceleration of type 1 diabetes by a coxsackievirus infection requires a preexisting critical mass of autoreactive T-cells in pancreatic islets. Diabetes. 2000;49(5):708-11. https://doi.org/10.2337/diabetes.49.5. 708.

56. Bach JF. The effect of infections on susceptibility to autoimmune and allergic diseases. N Engl J Med. 2002;347(12):911-20. https://doi.org/10.1056/NEJMra020100.

57. Laitinen $\mathrm{OH}$, Honkanen $\mathrm{H}$, Pakkanen O, Oikarinen S, Hankaniemi MM, Huhtala $\mathrm{H}$, et al. Coxsackievirus $\mathrm{B} 1$ is associated with induction of beta-cell autoimmunity that portends type 1 diabetes. Diabetes. 2014;63(2):446-55. https://doi.org/10.2337/db13-0619.

58. Hansson SF, Korsgren S, Ponten F, Korsgren O. Enteroviruses and the pathogenesis of type 1 diabetes revisited: cross-reactivity of enterovirus capsid protein (VP1) antibodies with human mitochondrial proteins. J Pathol. 2013;229(5):719-28. https:// doi.org/10.1002/path.4166.

59. Richardson SJ, Leete P, Dhayal S, Russell MA, Oikarinen M, Laiho JE, et al. Evaluation of the fidelity of immunolabelling obtained with clone 5D8/1, a monoclonal antibody directed against the enteroviral capsid protein, VP1, in human pancreas. Diabetologia. 2014;57(2):392-401. https://doi.org/10.1007/ s00125-013-3094-7.

60. Mercalli A, Lampasona V, Klingel K, Albarello L, Lombardoni C, Ekstrom J, et al. No evidence of enteroviruses in the intestine of patients with type 1 diabetes. Diabetologia. 2012;55(9):2479-88. https://doi.org/10.1007/s00125-012-2591-4.

61. Perrett KP, Jachno K, Nolan TM, Harrison LC. Association of rotavirus vaccination with the incidence of type 1 diabetes in children. JAMA Pediatr. 2019;173:280. https://doi.org/10.1001/ jamapediatrics.2018.4578.

62. Baggen J, Thibaut HJ, Strating JRPM, van Kuppeveld FJM. The life cycle of non-polio enteroviruses and how to target it. Nat Rev Microbiol. 2018;16(6):368-81. https://doi.org/10.1038/s41579-0180005-4.

63. Muehlenbachs A, Bhatnagar J, Zaki SR. Tissue tropism, pathology and pathogenesis of enterovirus infection. J Pathol. 2015;235(2):217-28. https://doi.org/10.1002/path.4438.

64. Li J, Lin C, Qu M, Li X, Gao Z, Zhang X, et al. Excretion of enterovirus 71 in persons infected with hand, foot and mouth disease. Virol J. 2013;10:31. https://doi.org/10.1186/1743-422X-10-31.

65. Svedin E, Utorova R, Huhn MH, Larsson PG, Stone VM, Garimella $\mathrm{M}$, et al. A link between a common mutation in CFTR and impaired innate and adaptive viral defense. J Infect Dis. 2017;216(10):1308 17. https://doi.org/10.1093/infdis/jix474.

66. Kundu R, Knight R, Dunga M, Peakman M. In silico and ex vivo approaches indicate immune pressure on capsid and non-capsid regions of coxsackie B viruses in the human system. PLoS One. 2018;13(6):e0199323. https://doi.org/10.1371/journal.pone. 0199323.

67. Ke Y, Liu WN, Her Z, Liu M, Tan SY, Tan YW, et al. Enterovirus A71 infection activates human immune responses and induces pathological changes in humanized mice. J Virol. 2019;93(3). https://doi.org/10.1128/JVI.01066-18.

68. Kemball CC, Harkins S, Whitmire JK, Flynn CT, Feuer R, Whitton JL. Coxsackievirus B3 inhibits antigen presentation in vivo, exerting a profound and selective effect on the MHC class I pathway. PLoS Pathog. 2009;5(10):e1000618. https://doi.org/ 10.1371/journal.ppat.1000618.

69. Deitz SB, Dodd DA, Cooper S, Parham P, Kirkegaard K. MHC Idependent antigen presentation is inhibited by poliovirus protein 3A. Proc Natl Acad Sci U S A. 2000;97(25):13790-5. https://doi. org/10.1073/pnas.250483097.

70. Huhn MH, Hultcrantz M, Lind K, Ljunggren HG, Malmberg KJ. Flodstrom-Tullberg M. IFN-gamma production dominates the early human natural killer cell response to Coxsackievirus infection. Cell Microbiol. 2008;10(2):426-36. https://doi.org/10.1111/j.1462-5822. 2007.01056.x.

71. Boppana S, Goepfert P. Understanding the CD8 T-cell response in natural HIV control. F1000Res. 2018;7. https://doi.org/10.12688/ f1000research.15029.1.

72. Cekin Y, Ozkaya E, Gulkesen H, Akcurin S, Colak D. Investigation of enterovirus infections, autoimmune factors and HLA genotypes in patients with T1DM. Minerva Endocrinol. 2014;39(1):67-74.

73. Craig ME, Howard NJ, Silink M, Rawlinson WD. Reduced frequency of HLA DRB $1 * 03-\mathrm{DQB} 1 * 02$ in children with type 1 diabetes associated with enterovirus RNA. J Infect Dis. 2003;187(10):1562-70. https://doi.org/10.1086/374742.

74. Heino L, Lonnrot M, Knip M, Kupila A, Erkkila S, Toivonen A, et al. No evidence of abnormal regulation of antibody response to 
coxsackievirus B4 antigen in prediabetic children. Clin Exp Immunol. 2001;126(3):432-6. https://doi.org/10.1111/j.1365-2249.2001.01691. $\mathrm{x}$.

75. Oikarinen S, Tauriainen S, Hober D, Lucas B, Vazeou A, SioofyKhojine A, et al. Virus antibody survey in different European populations indicates risk association between Coxsackievirus B1 and type 1 diabetes. Diabetes. 2014;63(2):655-62. https:// doi.org/10.2337/db13-0620.

76. Schernthaner G, Banatvala JE, Scherbaum W, Bryant J, Borkenstein M, Schober E, et al. Coxsackie-B-virus-specific IgM responses, complement-fixing islet-cell antibodies, HLA DR antigens, and C-peptide secretion in insulin-dependent diabetes mellitus. Lancet. 1985;2(8456):630-2.

77. Sadeharju K, Knip M, Hiltunen M, Akerblom HK, Hyoty H. The HLA-DR phenotype modulates the humoral immune response to enterovirus antigens. Diabetologia. 2003;46(8):1100-5. https://doi. org/10.1007/s00125-003-1157-x.

78. Zhou Z, Jensen PE. Structural characteristics of HLA-DQ that may impact DM editing and susceptibility to Type-1 diabetes. Front Immunol. 2013;4:262. https://doi.org/10.3389/fimmu.2013.00262.

79. Marttila J, Hyöty H, Näntö-Salonen K, Simell O, Ilonen J. Epitopes recognized by CBV4 responding T cells: effect of type 1 diabetes and associated HLA-DR-DQ haplotypes. Virology. 2004;319(1):27-35. https://doi.org/10.1016/j.virol.2003.10.011.

80. Bruserud O, Thorsby E. T lymphocyte responses to Coxsackie B4 and mumps virus. I. Influence of HLA-DR restriction elements. Tissue Antigens. 1985;26(1):41-50.

81. Ellis RJ, Varela-Calvino R, Tree TIM, Peakman M. HLA class II molecules on haplotypes associated with type 1 diabetes exhibit similar patterns of binding affinities for coxsackievirus $\mathrm{P} 2 \mathrm{C}$ peptides. Immunology. 2005;116(3):337-46. https://doi.org/10.1111/ j.1365-2567.2005.02233.x.

82. Dias Junior AG, Sampaio NG, Rehwinkel J. A balancing act: MDA5 in antiviral immunity and autoinflammation. Trends Microbiol. 2019;27(1):75-85. https://doi.org/10.1016/j.tim.2018.08.007.

83. Hultcrantz M, Hühn MH, Wolf M, Olsson A, Williams B, Korsgren $\mathrm{O}$, et al. Interferons induce an antiviral state in human pancreatic islets. Virology. 2007;367:92-101.

84. Huhn MH, McCartney SA, Lind K, Svedin E, Colonna M, FlodstromTullberg M. Melanoma differentiation-associated protein-5 (MDA-5) limits early viral replication but is not essential for the induction of type 1 interferons after Coxsackievirus infection. Virology. 2010;401(1): 42-8. https://doi.org/10.1016/j.virol.2010.02.010.

85. Wang JP, Cerny A, Asher DR, Kurt-Jones EA, Bronson RT, Finberg RW. MDA5 and MAVS mediate type I interferon responses to coxsackie B virus. J Virol. 2010;84(1):254-60. https://doi.org/10.1128/JVI.00631-09.

86. Nejentsev S, Walker N, Riches D, Egholm M, Todd JA. Rare variants of IFIH1, a gene implicated in antiviral responses, protect against type 1 diabetes. Science. 2009;324(5925):387-9. https:// doi.org/10.1126/science.1167728.

87. Smyth DJ, Cooper JD, Bailey R, Field S, Burren O, Smink LJ, et al. A genome-wide association study of nonsynonymous SNPs identifies a type 1 diabetes locus in the interferon-induced helicase (IFIH1) region. Nat Genet. 2006;38(6):617-9. https://doi.org/10.1038/ng1800.

88. Looney BM, Xia CQ, Concannon P, Ostrov DA, Clare-Salzler MJ. Effects of type 1 diabetes-associated IFIH1 polymorphisms on MDA5 function and expression. Curr Diab Rep. 2015;15(11): 96. https://doi.org/10.1007/s11892-015-0656-8.

89. Cinek O, Tapia G, Witso E, Kramna L, Holkova K, Rasmussen T, et al. Enterovirus RNA in peripheral blood may be associated with the variants of rs1990760, a common type 1 diabetes associated polymorphism in IFIH1. PLoS One. 2012;7(11):e48409. https:// doi.org/10.1371/journal.pone.0048409.

90. Witso E, Tapia G, Cinek O, Pociot FM, Stene LC, Ronningen KS. Polymorphisms in the innate immune IFIH1 gene, frequency of enterovirus in monthly fecal samples during infancy, and islet autoimmunity. PLoS One. 2011;6(11):e27781. https://doi.org/10.1371/ journal.pone.0027781.

91. Pang L, Gong X, Liu N, Xie G, Gao W, Kong G, et al. A polymorphism in melanoma differentiation-associated gene 5 may be a risk factor for enterovirus 71 infection. Clin Microbiol Infect. 2014;20(10): O711-O7. https://doi.org/10.1111/1469-0691.12618.

92. Jermendy A, Szatmari I, Korner A, Szabo AJ, Toth-Heyn P, Hermann R. Association between interferon-induced helicase (IFIH1) rs1990760 polymorphism and seasonal variation in the onset of type 1 diabetes mellitus. Pediatr Diabetes. 2018;19(2): 300-4. https://doi.org/10.1111/pedi.12569. This study suggests that the impact of a common polymorphism in the gene IFIH1 on T1D risk is strongest in the summer months.

93. Pons-Salort M, Oberste MS, Pallansch MA, Abedi GR, Takahashi S, Grenfell BT, et al. The seasonality of nonpolio enteroviruses in the United States: patterns and drivers. Proc Natl Acad Sci U S A. 2018;115(12):3078-83. https://doi.org/10.1073/pnas.1721159115.

94. Lincez PJ, Shanina I, Horwitz MS. Reduced expression of the MDA5 gene IFIH1 prevents autoimmune diabetes. Diabetes. 2015;64(6):2184-93. https://doi.org/10.2337/db14-1223.

95. Gorman JA, Hundhausen C, Errett JS, Stone AE, Allenspach EJ, Ge Y, et al. The A946T variant of the RNA sensor IFIH1 mediates an interferon program that limits viral infection but increases the risk for autoimmunity. Nat Immunol. 2017;18(7):744-52. https://doi.org/10.1038/ ni.3766.

96. Brownlie RJ, Zamoyska R, Salmond RJ. Regulation of autoimmune and anti-tumour T-cell responses by PTPN22. Immunology. 2018;154(3):377-82. https://doi.org/10.1111/imm.12919.

97. Wang Y, Shaked I, Stanford SM, Zhou W, Curtsinger JM, Mikulski Z, et al. The autoimmunity-associated gene PTPN22 potentiates toll-like receptor-driven, type 1 interferon-dependent immunity. Immunity. 2013;39(1):111-22. https://doi.org/10.1016/ j.immuni.2013.06.013.

98. Crabtree JN, He WQ, Guan WH, Flage M, Miller MS, Peterson EJ. Autoimmune variant PTPN22 C1858T is associated with impaired responses to influenza vaccination. J Infect Dis. 2016;214(2):248-57. https://doi.org/10.1093/infdis/jiw126.

99. Maine CJ, Teijaro JR, Marquardt K, Sherman LA. PTPN22 contributes to exhaustion of $\mathrm{T}$ lymphocytes during chronic viral infection. Proc Natl Acad Sci U S A. 2016;113(46):E7231-E9. https://doi.org/10.1073/pnas.1603738113.

100. Montes-Cano MA, Garcia-Lozano JR, Aguilar-Reina J, RomeroGomez M, Barroso N, Nunez-Roldan A, et al. PTPN22 C1858T polymorphism and the outcome of hepatitis $\mathrm{C}$ virus infection. Viral Immunol. 2008;21(4):491-4. https://doi.org/10.1089/vim.2008.0040.

101. Witso E, Cinek O, Tapia G, Brorsson CA, Stene LC, Gjessing HK, et al. Genetic determinants of enterovirus infections: polymorphisms in type 1 diabetes and innate immune genes in the MIDIA study. Viral Immunol. 2015;28(10):556-63. https://doi.org/10.1089/vim.2015. 0067.

102. Rowshanravan B, Halliday N, Sansom DM. CTLA-4: a moving target in immunotherapy. Blood. 2017:blood-2017-06-741033. https://doi.org/10.1182/blood-2017-06-741033.

103. Yang KD, Yang MY, Li CC, Lin SF, Chong MC, Wang CL, et al. Altered cellular but not humoral reactions in children with complicated enterovirus 71 infections in Taiwan. J Infect Dis. 2001;183(6):850-6. https://doi.org/10.1086/319255.

104. Han B, Jiang H, Liu Z, Zhang Y, Zhao L, Lu K, et al. CTLA4-Ig relieves inflammation in murine models of Coxsackievirus B3induced myocarditis. Can J Cardiol. 2012;28(2):239-44. https:// doi.org/10.1016/j.cjca.2011.11.014.

105. Rose NR. Viral myocarditis. Curr Opin Rheumatol. 2016;28(4): 383-9. https://doi.org/10.1097/bor.0000000000000303.

106. Wallden J, Ilonen J, Roivainen M, Ludvigsson J, Vaarala O, Group AS. Effect of HLA genotype or CTLA-4 polymorphism on 
cytokine response in healthy children. Scand J Immunol. 2008;68(3):345-50. https://doi.org/10.1111/j.1365-3083.2008. 02144.x.

107. Rojas JM, Avia M, Martín V, Sevilla N. IL-10: a multifunctional cytokine in viral infections. J Immunol Res. 2017;2017:1-14. https://doi.org/10.1155/2017/6104054.

108. Hofmann P, Schmidtke M, Stelzner A, Gemsa D. Suppression of proinflammatory cytokines and induction of IL-10 in human monocytes after coxsackievirus B3 infection. J Med Virol. 2001;64(4):487-98.

109. Schmidtke M, Gluck B, Merkle I, Hofmann P, Stelzner A, Gemsa D. Cytokine profiles in heart, spleen, and thymus during the acute stage of experimental coxsackievirus B3-induced chronic myocarditis. J Med Virol. 2000;61(4):518-26. https://doi.org/10.1002/ 1096-9071(200008)61:4<518::Aid-Jmv16>3.0.Co;2-F

110. Cen ZH, Guo YJ, Kong Q, Zhou QX, Wu WF. IL-10-producing B cells involved in the pathogenesis of Coxsackie virus B3-induced acute viral myocarditis. Int J Clin Exp Pathol. 2015;8(1):830-5.

111. Vreugdenhil GR, Wijnands PG, Netea MG, van der Meer JW, Melchers WJ, Galama JM. Enterovirus-induced production of proinflammatory and T-helper cytokines by human leukocytes. Cytokine. 2000;12(12):1793-6. https://doi.org/10.1006/cyto.2000.0786.

112. Chen ZF, Li RQ, Xie ZC, Huang GQ, Yuan QC, Zeng JC. IL-6, IL10 and IL-13 are associated with pathogenesis in children with Enterovirus 71 infection. Int J Clin Exp Med. 2014;7(9):2718-23.

113. Han J, Wang Y, Gan X, Song J, Sun P, Dong XP. Serum cytokine profiles of children with human enterovirus 71-associated hand, foot, and mouth disease. J Med Virol. 2014;86(8):1377-85. https://doi.org/10.1002/jmv.23929.

114. Ye N, Gong X, Pang L-L, Gao W-J, Zhang Y-T, Li X-L, et al. Cytokine responses and correlations thereof with clinical profiles in children with enterovirus 71 infections. BMC Infect Dis. 2015;15(1):225. https://doi.org/10.1186/s12879-015-0965-1.

115. Qian B-X, Ye Q, Zhao X-Y, Han T, Wang F-M, Yang J. Metaanalysis of the relation between IL10 promoter polymorphisms and autoimmune liver disease risk. Genet Test Mol Biomarkers. 2018;22(5):302-13. https://doi.org/10.1089/gtmb.2018.0010.

116. Manolova I, Miteva L, Ivanova M, Kundurzhiev T, Stoilov R, Stanilova S. The synergistic effect of TNFA and IL10 promoter polymorphisms on genetic predisposition to systemic lupus erythematosus. Genet Test Mol Biomarkers. 2018;22(2):135-40. https:// doi.org/10.1089/gtmb.2017.0169.

117. Zhao N, Chen H-L, Chen Z-Z, Li J, Chen Z-B. IL-10-592 polymorphism is associated with IL-10 expression and severity of enterovirus 71 infection in chinese children. J Clin Virol. 2017;95: 42-6. https://doi.org/10.1016/j.jcv.2017.08.005.

118. Yang J, Zhao N, Su NL, Sun JL, Lv TG, Chen ZB. Association of interleukin 10 and interferon gamma gene polymorphisms with enterovirus 71 encephalitis in patients with hand, foot and mouth disease. Scand J Infect Dis. 2012;44(6):465-9. https://doi.org/10. 3109/00365548.2011.649490.

119. Yeung WCG, Al-Shabeeb A, Pang CNI, Wilkins MR, Catteau J, Howard NJ, et al. Children with islet autoimmunity and enterovirus infection demonstrate a distinct cytokine profile. Diabetes. 2012;61(6):1500-8. https://doi.org/10.2337/db11-0264.

120. Gu R, Shampang A, Reilly A, Fisher D, Glass W, Ramsingh AI. Dynamics of molecular responses to coxsackievirus B4 infection differentiate between resolution and progression of acute pancreatitis. Virology. 2012;427(2):135-43. https://doi.org/10.1016/j.virol.2012. 02.009 .

121. Zammit NW, Grey ST. Emerging roles for A20 in islet biology and pathology. Adv Exp Med Biol. 2014;809:141-62.

122. Fukaya M, Brorsson CA, Meyerovich K, Catrysse L, Delaroche D, Vanzela EC, et al. A20 inhibits beta-cell apoptosis by multiple mechanisms and predicts residual beta-cell function in type 1 diabetes. Mol Endocrinol. 2016;30(1):48-61. https://doi.org/10.1210/me.2015-1176.
123. Krischer JP, Liu X, Lernmark A, Hagopian WA, Rewers MJ, She JX, et al. The influence of type 1 diabetes genetic susceptibility regions, age, sex, and family history on the progression from multiple autoantibodies to type 1 diabetes: a TEDDY study report. Diabetes. 2017;66(12):3122-9. https://doi.org/10.2337/db17-0261.

124. Gui J, Yue Y, Chen R, Xu W, Xiong S. A20 (TNFAIP3) alleviates CVB3-induced myocarditis via inhibiting NF-kappaB signaling. PLoS One. 2012;7(9):e46515. https://doi.org/10.1371/journal. pone. 0046515 .

125. Doukas T, Sarnow P. Escape from transcriptional shutoff during poliovirus infection: NF-kappaB-responsive genes IkappaBa and A20. J Virol. 2011;85(19):10101-8. https://doi.org/10.1128/JVI.00575-11.

126. Feng W, Sun X, Shi N, Zhang M, Guan Z, Duan M. Influenza a virus NS1 protein induced A20 contributes to viral replication by suppressing interferon-induced antiviral response. Biochem Biophys Res Commun. 2017;482(4):1107-13. https://doi.org/10. 1016/j.bbrc.2016.11.166.

127. Song X, Yao Z, Yang J, Zhang Z, Deng Y, Li M, et al. HCV core protein binds to $\mathrm{gClqR}$ to induce $\mathrm{A} 20$ expression and inhibit cytokine production through MAPKs and NF-kappaB signaling pathways. Oncotarget. 2016;7(23):33796-808. https://doi.org/10. 18632/oncotarget.9304.

128. Leonard WJ, Wan C-K. IL-21 Signaling in Immunity. F1000Research. 2016;5. https://doi.org/10.12688/ f1000research.7634.1.

129. Bayer AL, Pugliese A, Malek TR. The IL-2/IL-2R system: from basic science to therapeutic applications to enhance immune regulation. Immunol Res. 2013;57(1-3):197-209. https://doi.org/10. 1007/s12026-013-8452-5.

130. Dooms $\mathrm{H}, \mathrm{Abbas}$ AK. Revisiting the role of IL-2 in autoimmunity. Eur J Immunol. 2010;40(6):1538-40. https://doi.org/10.1002/eji. 201040617.

131. Dwyer CJ, Ward NC, Pugliese A, Malek TR. Promoting immune regulation in type 1 diabetes using low-dose Interleukin-2. Curr Diab Rep. 2016;16(6):46. https://doi.org/10.1007/s11892-016-0739-1.

132. Gharibi T, Majidi J, Kazemi T, Dehghanzadeh R, Motallebnezhad M, Babaloo Z. Biological effects of IL-21 on different immune cells and its role in autoimmune diseases. Immunobiology. 2016;221(2):35767. https://doi.org/10.1016/j.imbio.2015.09.021.

133. Liu W, Dienz O, Roberts B, Moussawi M, Rincon M, Huber SA. IL21R expression on CD8+ T cells promotes CD8+ T cell activation in coxsackievirus B3 induced myocarditis. Exp Mol Pathol. 2012;92(3): 327-33. https://doi.org/10.1016/j.yexmp.2012.03.009.

134. Yang F, Wei X-m, Liang W-w, Mo W-h, Tan B-p, Wang H. A critical role for IL-21 receptor signaling in the Coxsackievirus B3-induced myocarditis. Inflammation. 2017;40(4):1428-1435. doi:https://doi.org/10.1007/s10753017-0586-5.

135. Ozer G, Teker Z, Cetiner S, Yilmaz M, Topaloglu AK, Onenli-Mungan N, et al. Serum IL-1, IL-2, TNFalpha and INFgamma levels of patients with type 1 diabetes mellitus and their siblings. J Pediatr Endocrinol Metab. 2003;16(2): 203-10.

136. Lee JY, Son M, Kang JH, Choi UY. Serum interleukin-6 levels as an indicator of aseptic meningitis among children with enterovirus 71induced hand, foot and mouth disease. Postgrad Med. 2018;130(2): 258-63. https://doi.org/10.1080/00325481.2018.1416257.

137. Kishimoto C, Kuroki Y, Hiraoka Y, Ochiai H, Kurokawa M, Sasayama S. Cytokine and murine Coxsackievirus B3 myocarditis - interleukin-2 suppressed myocarditis in the acute stage but enhanced the condition in the subsequent stage. Circulation. 1994;89(6):2836-42. https://doi.org/10.1161/01.Cir.89.6.2836.

138. Onengut-Gumuscu S, Chen WM, Robertson CC, Bonnie JK, Farber E, Zhu Z, et al. Type 1 diabetes risk in African-ancestry participants and utility of an ancestry-specific genetic risk score. Diabetes Care. 2019;42(3):406-15. https://doi.org/10.2337/dc18-1727. 
139. Ritchie MD, Van Steen K. The search for gene-gene interactions in genome-wide association studies: challenges in abundance of methods, practical considerations, and biological interpretation. Ann Transl Med. 2018;6(8):157. https://doi.org/10.21037/atm.2018.04.05.

140. Triolo TM, Fouts A, Pyle L, Yu L, Gottlieb PA, Steck AK, et al. Identical and nonidentical twins: risk and factors involved in development of islet autoimmunity and type 1 diabetes. Diabetes Care. 2019;42(2):192-9. https://doi.org/10. 2337/dc18-0288.

141. Hankaniemi MM, Laitinen OH, Stone VM, Sioofy-Khojine A, Maatta JAE, Larsson PG, et al. Optimized production and purification of Coxsackievirus B1 vaccine and its preclinical evaluation in a mouse model. Vaccine. 2017;35(30):3718-25. https://doi.org/ 10.1016/j.vaccine.2017.05.057.

142. Stone VM, Hankaniemi MM, Svedin E, Sioofy-Khojine A, Oikarinen S, Hyoty H, et al. A Coxsackievirus B vaccine protects against virus-induced diabetes in an experimental mouse model of type 1 diabetes. Diabetologia. 2018;61(2):476-81. https://doi.org/10.1007/s00125-017-4492-z. This study shows that a vaccine prevents from CVB infection and virus-induced T1D in an animal model.

143. Wickham. ggplot2 Elegant Graphics for Data Analysis. Springer; 2016.

144. Walter W, Sanchez-Cabo F, Ricote M. GOplot: an R package for visually combining expression data with functional analysis. Bioinformatics. 2015;31(17):2912-4. https://doi.org/10.1093/ bioinformatics/btv300.

Publisher's Note Springer Nature remains neutral with regard to jurisdictional claims in published maps and institutional affiliations. 